\title{
Functional foreign language literacy for global research career development: analysis of standardized open-ended interview responses
}

\author{
Oksana Chigisheva - Elena Soltovets - Anna Bondarenko
}

\section{DOI: $10.18355 /$ XL.2017.10.04.12}

\begin{abstract}
The article explores the links between functional foreign language literacy and opportunities for global research career development. The relevance of the study is due to the rising trends of labor market globalization and internationalization of science and education domain. The purpose of the paper is to clarify the extent to which foreign language literacy can shape would-be researchers' aspirations and career development plans. Phenomenological approach uderpins research procedures and reserch methodology. Standardized open-ended interview responses of $45 \mathrm{PhD}$ students of Southern Federal University were analyzed to address the concepts of functional literacy and functional foreign language literacy from self-reflexive perspective. The present study also discusses acquisition of functional foreign language literacy in terms of positive and negative factors as well as the $\mathrm{PhD}$ students` perceptions of its role in developing global research career. The research findings are to inform educational policy and practice worldwide on the existing issues of concern in the area of researcher training.
\end{abstract}

Key words: functional literacy, functional foreign language literacy, global research career development, phenomenological approach, standardized open-ended interview

\section{Introduction}

Globalisation is seen as a main trend shaping all spheres of human life in the XXI century that has led to the emergence of global knowledge economy and fast technological transformations that in its turn "have resulted in the global competition phenomenon that is currently reshaping the higher education subsector" (Portnoi et al., 2010: 1). This key message is specifically stressed in the executive summary of the OECD Centre for Educational Research and Innovation (Trends shaping innovation, 2016: 9) where it is also pointed at the need for educational internationalisation due to the increasing migration rates since 1985, the rise of multinational companies expanding globally and growing challenges of international intergovernmental cooperation. OECD is calling for new initiatives to develop global contacts in the sphere of higher education in the future and emphasizing the need for encouraging foreign language learning (Trends shaping innovation, 2016: 38).

Current "reputation race" (van Vught, 2008) in higher education and research may be traced at the local, regional, national, global and even personal level where academic prestige and reputation value a lot. In the situation when educational and research institutions heavily "compete for research funding, the "best and brightest" international students, and "star" faculty members" (Portnoi et al., 2010: 1) the role of intellectual capital is growing fast (Draskovic et al., 2017: 323). It inevitably leads to the institutional changes, intensification of cross-border partnerships in academe, internationalization of academic research, scientific interdependence and stimulates various integration processes in the European area or worldwide (Cross-border Partnerships in Higher Education. Strategies and Issues, 2010; Chigisheva, 2015).

Like most of the member countries of the Bologna Process, Russia has been undergoing through a stage of internalisation of its system of higher education. The special role of education in human resources development is recognized in the President's Decree N 967 “'On measures to develop human resource potential of the 
Russian Federation" (2013). The Concept of the Federal Targeted program "Development of education for 2016-2020" (2014) puts forward the idea of increasing international competetive advantage of Russian graduates as its leading objective. During the last decade Russian universities and educational institutions have been trying to improve their positions in global university ranking systems by introducing various programmes on students and staff academic mobility (Erasmus+, DAAD, Fulbright Program), institutional partnerships (US-Russia University Partnership Program, Jean Monnet Programme), joint research projects (Scientific \& Technological Cooperation Programme Switzerland-Russia, BILAT-RUS-Advanced project, EuRuCAS project) that are stated among key quality indicators. The teaching staff and doctoral students have been encouraged and sometimes even urged to demonstrate high integration into the global scientific and educational environment.

However, according to a number of researchers, the level of internationalisation of Russian tertiary education is still questionable to some extent due to marketization of higher education influencing its quality as well as possibilities for social mobility and equality (Smolentseva, 2017); inadequate international visibility of Russian researchers at the global level and insufficient scientific integration into global science (Kirtchik, 2012; Marginson, 2014); low attractiveness of Russian higher education for international students (Stukalova et al., 2015). At the same time a lot is being done now at the governmental level to crucially change the situation and strengthen the position of Russian higher education at the global research and higher education market. The evidence here are the State Program Global Education (2014) and priority project Development of the export potential of the Russian system of education (2017) which is aimed to increase the attractiveness of Russian higher education programs for foreigners within the period of 2017-2025.

Global Education was launched by the government of the Russian Federation in 2014 as a measure of state support for modernization and technological enhancement of reforms in the social sector. Being the analogue of educational grant for covering major financial expenses of Russian citizens admitted to one of 288 leading foreign higher educational institutions in 32 countries of the world, the programme was believed to boost the rates of Russian scientists' international presence at Master and Doctoral level (education, medicine, engineering, sciences, social management) and staff Russian organisations with highly-qualified personel, including the Far East and Eastern Siberia, after their return home. Surprisingly, the programme has not been as popular as it had been expected, despite the fact that the eligibility requirements were not very hard to meet. It was supposed to finance 718 students within 2 years period (2014-2016) and close the program, but the real number of 150 students turned ridiculously small compared to the initial target indicator and it was decide to relaunch the program again till 2020 (The program "Global education" will be extended, 2016).

This failure can be related to a number of deterrent factors. Among the most obvious is liability to return to Russia upon completion of the studies and the compulsory employment for a period of at least 3 years. As a result, students have to lose international contacts and refuse a number of promising job offers. A limited number of scientific spheres prioritised for the program are considered problematic. Moreover, they are thought to be psychologically exhausting and time and money consuming (Yakovleva, 2016). Another popular concern is articulated on the program website by one of the participants as "I would strongly suggest anyone interested in the <Global Education> programme should start learning a foreign language and take international language certificate exams" (Nurgaliev Albert, Carnegie Mellon University). The importance of the program for mastering foreign language is also mentioned: "I would recommend all those still in doubt to fear nothing and to take part in the program. You will obtain international knowledge and experience, as well

XLinguae, Volume 10, Issue 4, October 2017, ISSN 1337-8384, eISSN 2453-711X 
as language proficiency" (Serovaisky Alexander, Royal Institute of Technology, Stockholm) (State Program Global Education, 2014).

Both projects demonstrate a strong focus on the relevance of international interaction in the sphere of education and culture alongside with the ambitious aim of attracting enthusiastic, talented and competitive human resources to the sector of Russian economy for its intensive development. Such approach seems logical in the context of competition phenomenon and progressing globalization causing changes in the qualification parameters of academic workforce at the global labor market. In this regard, language learning has faced increasing attention from syllabi designers, to say nothing of the public. Nevertheless, the complaints have continuously been heard as for the ability of learners to function in real life situations. The same is true of the researchers who tend to refer to language barrier if asked about the lack of international contacts and cooperation.

These ideas are proved by a number of controversies that are easily detected in contemporary Russian research and educational reality. Firstly, due to the growing gap between the urgent necessity to interact within international academic community and the lack in understanding of the significant role of functional/functional foreign language literacy in this process. Secondly, because of imbalance between fast globalizing and changing educational and scientific reality and heightened awareness of need and real opportunities for professional transformations at the institutional and personal levels. Thirdly, due to the critical demands at the international labor market for professional and linguistic qualifications of researchers and their level of functional literacy in these areas as well as the lack of the necessity to take concrete steps as a result of low motivation.

Thus, the purpose of this paper is to investigate if functional language literacy allows not to be left at the knowledge and professional periphery in the era of globalisation? And is it a key prerequisite for successful global research career development?

From this position it is possible to do by examining: 1) how functional/functional foreign language literacy has been treated historically in education; 2) standardized open-ended interview responses of Russian PhD students (Education only) in relation to functional/functional foreign language literacy awareness, key factors shaping it and the role of functional foreign language literacy for global research career development.

\section{Literature Review}

Starting from 1957 the concept of functional literacy has been actively developed by UNESCO and in 1965 at the World Congress of Ministers of Education on the Eradication of Illiteracy in Teheran (Iran) the concepts of "literacy" and "functional literacy" were clearly demarcated. Since 1978 functional literacy has been understood as a form of training a person for his/her social, civic and economic role in the society, while "minimum literacy" indicators such as reading, writing and counting were considered as absolute requirements for personal growth contributing to society development (UNESCO, 1978). These concepts were further refined in the Education for All Global Monitoring Reports and UNESCO Annual Education for All Reports. They were also implicitly researched in a number of publications by modern Russian and European theorists and practitioners who addressed the issues related to the "new literacy" of the XXI century (Kolesnikova, 2013) and functional foreign language literacy (Chigisheva et al., 2016; Uhuegbu, Edung, 2015), studied functional medical (Tsubakita et al., 2017) and financial literacy (Han et al., 2016) as well as adult literacy as a mechanism of social inclusion (Kuz`mina, Popov, 2015).

Of special interest to our research are the debates on the understanding of functional literacy in modern educational discourse. Thus, some researchers perceive it as a basis for the formation of competent individual able to solve successfully functional 
problems that he/she faces (Lebedev, 2005), others understand functional literacy as an ability to act efficiently in real life and emphasize deep social and philosophical sense of this concept, which implies involving an individual into serious educational activity, active mastery of professional information with further realization of learners`vital aspirations at personal and social levels (Klyucharev, Ogarev, 2002).

When defining functional literacy Matskevich V. and Krupnik S. (2001) also stress its social dimension emphasizing that "functional literacy is the ability of a person to interact with the external environment and adapt as fast as possible and function in it" (Matskevich, Krupnik, 2001: 312). At the same time, according to the authors, the differences in interpretations of functional literacy depend on the influence of various social factors and contextual focuses chosen for its consideration. Vershlovsky S.G. and Matyushkina M.D. (2007) directly connect the level of functional literacy with the level of society`s technological development and its well-being, and believe that "functional literacy is a way of social orientation of the individual, integrating the connection between education (primarily general) and multidimensional human activity" (Vershlovsky, Matyushkina, 2007: 141). At the same time, the authors single out such types of functional literacy as general, computer, information, literacy of actions in emergency situations, foreign language literacy, literacy in solving everyday problems, legal, socio-political and communicative literacy. Rich variety of functional literacy types testifies the emergence of new thematic contexts allowing new understandings and interpretations.

This conclusion is supported by the position of Basova E.A. (2012) who provides the concept of functional communicative literacy with theoretical and practical rationale. She considers it through the prism of key communicative skills of an individual that are extremely important due to the growth of communicative interactions at all societal levels. The author views this type of functional literacy as the most important indicator of a certain level of individual educational achievements that allows easy communication in various standard and non-standard situations following existing communicative norms, rules of oral and written text creation and peculiarities of work with various kinds of information.

However, few studies have been undertaken and relatively little has been published on functional foreign language literacy and its role in the global research career development. Some authors have aimed to specify the value of functional foreign language literacy for the sphere of higher education and research (Uhuegbu, Edung, 2015) and investigating literacy in second and foreign language instruction (Kern \& Schultz, 2005). A number of publications are fully devoted to the methodical questions in language learning observing either the strategies to support English language learners in social sciences (Zhang, 2017) and techniques for developing intercultural communicative competences (Reid, 2015) or simply providing general overview of language teaching principles in relation to changing realities of the XXI century (Larsen-Freeman, Anderson, 2011).

From this point, the article "From early career researcher to research leader: survival of the fittest?" (Browning et al., 2017) provokes direct reflections on interdependence between global research career success and functional foreign language literacy as the most common factors critical for progress are having good international connections and networks and participating in collaborative research. It is noted that $\mathrm{PhD}$ and the early career stages are crucial for researchers to make a name for themselves at a global scientific arena through innovative research projects, collaborative joint activities and research communication.

\section{Research Methodology}

Research design

XLinguae, Volume 10, Issue 4, October 2017, ISSN 1337-8384, eISSN 2453-711X 
Starting from the document "Towards a European Framework for Research Careers" (2011) where the main stages of global research career development were offered (R1-R4), modern researcher started to be perceived as a "professional engaged in the conception or creation of new knowledge, products, processes, methods and systems and also in the management of the projects concerned' (Towards a European Framework for Research Careers, 2011: 2). It has put a stress on the main criterion of researcher`s career development, i.e. high quality internationally oriented research inevitably demanding high level of functional foreign language literacy from the researcher. This idea was officially recognized at the highest levels, but there`s little to be said by the researchers themselves of how they feel on the matter. That is why a phenomenological approach was selected for this study. It allowed to identify the studied phenomenon of functional foreign language literacy from the personal perspective of the researchers, compare their experiences and interpretations, gain insights into their career motivations, actions and possible research career advantages worldwide (Groenewald, 2004, Fedotova, 2015).

Standardized open-ended interviews were used to fix individual perceptions of the phenomenon by the respondents using the same basic sequence of questions in the same order as presented in Table 1. Questions 1-3 served to ensure functional literacy and functional foreign language literacy of the interviewees, questions 4-6 highlighted key factors shaping functional foreign language literacy, and questions 7-9 elicited opinions related to the role of functional foreign language literacy for global research career development. The fact that all respondents answered the same pre-determined questions considerably increased comparability of responses and allowed to complete the necessary data for each person in full (Research Methods in Education, 2007). It permitted to reduce interviewers' effects and bias that may be determined as an advantage.

Table 1: Standardized Open-Ended Interview Questions

\begin{tabular}{|c|c|}
\hline $\mathbf{N}$ & Questions \\
\hline 1 & What is functional literacy? \\
\hline 2 & What is functional foreign language literacy? \\
\hline 3 & How good is your functional foreign language literacy? \\
\hline 4 & $\begin{array}{l}\text { What are the positive factors contributing to the development of } \\
\text { functional foreign language literacy? }\end{array}$ \\
\hline 5 & $\begin{array}{l}\text { What are the negative factors adversely affecting the development of } \\
\text { functional foreign language literacy? }\end{array}$ \\
\hline 6 & $\begin{array}{l}\text { What changes in the teaching and learning process can be potentially } \\
\text { beneficial for the development of foreign language literacy? }\end{array}$ \\
\hline 7 & $\begin{array}{l}\text { Is functional foreign language literacy a competitive advantage for the } \\
\text { research career and why? }\end{array}$ \\
\hline 8 & Where and how are you going to pursue your research career? \\
\hline 9 & $\begin{array}{l}\text { Are you planning to maintain the level of your functional foreign } \\
\text { language literacy in the future? If no, why? If yes, in what ways? }\end{array}$ \\
\hline
\end{tabular}




\section{Research procedures and participants}

Standardized open-ended interviews were conducted with $\mathrm{PhD}$ students (Education only) of the Academy of Psychology and Educational Sciences at Southern Federal University (Rostov-on-Don, Russia). 45 respondents out of total 62 $\mathrm{PhD}$ students were interviewed on a voluntary basis from April through May 2017. Each interview was conducted either in person or through Skype videoconferencing application, audio recorded and later transcribed for deep contextual research analysis. All researchers followed previously defined instructions.

At the time of the study group 1 consisted of 22 first-year PhD students, group 2 was represented by 18 second-year $\mathrm{PhD}$ students and group 3 - by 5 third-year $\mathrm{PhD}$ students. All of them had different levels of English language proficiency, first-year $\mathrm{PhD}$ students were still in the process of learning it and second and third-year students had already passed their qualification English language exam at the end of the first year of studies.

It should be noted that all first-year PhD students at Southern Federal University have a 2 semester course of English that equals 144 hours, i.e. 100 contact hours, 17 hours of individual work and 27 hours for continuous assessment by the instructor. The choice of teaching materials depends on the level of the group (from Pre-Intermediate to Advanced), but most of the studied themes are related to research, science and education. Monthly individual work comprises reading articles and books in the field of $\mathrm{PhD}$ students` research (30-40 pages) and written translation of research literature passages from English into Russian (300-500 words). After completion of the annual language course of studies and passing qualification English language exam $\mathrm{PhD}$ students are supposed to find individual opportunities for mastering language knowledge in their research work and professional sphere.

\section{Results and Discussion}

The concept of "functional foreign language literacy" was at the core of the study and was considered in the global research context as an ability to use a foreign language to function efficiently in a multidisciplinary, collaborative, internatioanal professional environment. With English being universally understood as the language of international communication, the respondents did not have to specify every time what language was referred to as "foreign". Moreover, all the survey participants were studying English as a second language, so in their answers the words "foreign language" and "English language" were used interchangeably.

\section{The notions of functional literacy and funcitonal foreign language literacy}

As it became clear from the interview results, the term "functional literacy" is far from being widely known. When asked to give a definition of functional literacy, 27 out of 45 respondents admitted never having heard of the term before. Two respondents made an immediate attempt to google the collocation on the pretext of knowing the term but being unable to give "correct" definition. It should be specifically noted that some of the students were willingly trying to make guesses of its meaning. Not all of the guesses were successful.

A direct association with the term of functional literacy is the phenomenon of functional disease, a disorder of all functions of the whole system of human body. So, as I understand, functional literacy is the kind of literacy that embraces all aspect of a person 's functioning. Though, I can't tell you in details what exactly it might involve. (Respondent 14)

It's really difficult to say. May be, it is using the language in an appropriate way in various spheres of human activity. (Respondent 29) 
A number of participants could not make clear distinction between literacy and functional literacy, being prone to confusion and misunderstanding. 2 respondents believed literacy to be the general term, with functional literacy denoting specific literacy in various aspects, such as reading or writing.

Two of the respondents were quite quick in tracing the connection with person's activity and environment.

\section{For me, first of all it is connected with the occupation or the profession that you have or the functions you perform. So, you have a clear vision of what you have to do and how you are supposed to act to fulfill your functions. (Respondent 3)}

The nature of functional activity of a person in the surrounding world was quite obvious for most of those guessing. Though, none of them discovered the idea of adapting and adjusting to the environment that is provided by this type of literacy. They also failed to mention social nature of functional literacy.

On the contrary, social communication stood out when functional foreign language literacy was concerned. In their definitions most of the respondents (16 out of 27) pointed out that such type of literacy might account for a person's ability to communicate with foreign language speakers "in a proper way" (Respondents 6, 17, 41). 5 people mentioned having the level of foreign language command sufficient for functioning as a specialist in one's sphere.

As I see it, it must have something to do with using foreign language on the level of professional communication. (Respondent 42)

Well, it sounds as if a person functions...er, I guess functions professionally, using some foreign language. As if a foreign language is a prerequisite for such functioning. (Respondent 11)

However, there were answers that showed little correlation with the true meaning of the term. Some participants were obviously misled by "foreign language" and tried to reconstruct the meaning on the basis of some linguistic attributes.

Functional foreign language literacy in knowing how different language structures function in the most suitable and natural way in the language. (Respondent 35)

I would say it's all about functional adequacy of the linguistic means people choose when they try to speak a foreign language. We all know that sometimes you can speak more or less correct English but you sound absolutely funny and weird to a native speaker. (Respondent 29)

Paradoxically, one of these respondents was a person with a high level of spoken English who claimed to have had her Bachelor's degree in linguistics. What is more explicable, but of quite an interest, she was the only person who made a clear statement of having well-developed functional foreign language literacy. 3 other respondents were not sure of being functionally literate enough but did not hesitated to say performing functional responsibilities in English had never been a challenge . None of them, though, mentioned participating in international scientific events or having their works published outside Russia as an argument to support their opinions. 
I am not $100 \%$ sure. I think I am rather literate <in what concerns functional foreign language >. I have had to communicate with foreign speakers through e-mail discussing my thesis paper. I also made a presentation in English at one of the university students' conferences and I think I did pretty well. (Respondent 17)

Of course I can't say I am perfect in it, but so far I've had no problems. I mean I understood all the books in the list that was given to us by our teachers. (Respondent 8)

The rest of the participants expressed their concerns about their level of functional foreign language literacy. 15 students denied having any, 16 students reported having considerable difficulties with using English for research and professional matters. 10 respondents said they knew their English was very poor and they had already experienced problems with using it in academic environment. It is really worth noting that most of the students referred to their teachers and academic grades when they were trying to assess their functional foreign language literacy. 2 students said their vocabulary was not rich enough, 4 respondents were dissatisfied with their grammar and ability to form correct sentences. Some students seemed puzzled when asked about the criteria of self-assessment. 3 students said they had a "feeling", 5 respondents failed to put into words what were the grounds for their assessment. "It < functional foreign language literacy > leaves much to be desired", "It is obviously not enough" and "I just know it is bad" were the most popular answers $(6,5$ and 5 respectively).

Factors influencing functional foreign language literacy development

The respondents were asked to identify the key forces shaping the process of functional foreign language literacy development. The positive driving forces were not always obvious for the learners and thus were more difficult to elicit. The students were mostly concentrating on classroom learning, being apt to underestimate the effect of independent learning. 42 out of 45 respondents mentioned among positive factors various aspects of teaching process, while only 18 people were ready to take responsibility for their own study. This being said, however, over half of the respondents (31) stressed the importance of out-of-classroom experience.

The class-related factors mentioned by the respondents were as follows (in the frequency order):

- up-dated and efficient textbooks;

- the sufficient number of classes and lessons of English taken at university;

- $\quad$ qualified teachers who possess functional foreign language literacy;

- modern, flexible and versatile teaching methods, tailored training activities;

- $\quad$ good entry level of English for general purposes.

It really helps when a teacher is not only a grammar and vocabulary explainer but a specialist in your sphere of knowledge as well. At the very least he or she should be a practicing researcher who understands the challenges facing a young scientist. (Respondent 22)

I am not complaining in any way, but we used to spend too much time in class drilling and revising. It worked well, but focusing on the skills necessary for article writing or round-table discussion would have been be

XLinguae, Volume 10, Issue 4, October 2017, ISSN 1337-8384, eISSN 2453-711X 
a great benefit. It might be helpful when your teacher of English is functionally literate, as you put it. (Respondent 45)

The students often said that having one lesson of English a week is not enough to maintain the level of functional foreign language literacy and gives no chance for developing it. So, 18 respondents noted that self-study and autonomous revision are crucial.

A good learner should spend at least 15 minutes a day revising. Regular
practice works miracles. Knowing your "trouble areas" and working on
them conscientiously is a great booster. (Respondent 26)

Brush up your knowledge as often as you can. General language literacy is like a basis for more sophisticated English. Keep it all right and it will help you greatly to move on with mastering the language of business correspondence or scientific debates. (Respondent 23)

The most powerful factor, according to most respondents, was the need to use the knowledge in real life situations. In different ways this idea was expressed by many students (31) and stressed by some of them (12).

It is vital to communicate with the language speaker on non-academic matters, I mean, when this is not a part of your home assignment but a natural communication. Native speakers are very kind, friendly and tolerant, they try to turn a blind eye to the learner's mistakes and are always ready to help. It is really astonishing how encouraging real-life communication is! (Respondent 8)

Modern trends....I say, globalization, internalization of education, modern information technologies... you name it... Well, all of this leaves you no chance of working isolatedly. It is just not possible in modern world. As soon as you discover it and face the real life demand of using English...Do you see what I am driving at? Having to use English in you daily life and work is the most influential factor of all.(Respondent 16)

Though the idea of practical importance was quite common, the word "motivation" was mentioned only by 4 respondents. Interestingly, all of them ranked motivation first in their lists and seemed willing to develop this topic for a long time. One of them noted that motivation can hardly be imposed on learners and should be rooted in everyday activity in a most natural way.

It is even more remarkable that the same idea was expressed by the overwhelming majority when negative factors were concerned. Answering the question what factors have an adverse effect on developing functional foreign language literacy most of the participants (32 out of 45) started from the lack of motivation. The issue of motivation was a common thread running through the whole bulk of students' answers, though being conveyed in different ways.

Most students are lazy! Well, I may sound a bit self-deprecating, but I mean that if you can afford having fun instead of learning, you just do it. Again, it may sound wrong. What I really mean is that you always do things which you really feel you need to do. The things that you feel are necessary and helpful. Your personal interest is the best motivator as long as you can see benefits for your everyday life and work. Well, of course, everybody knows 
how important it is to learn English! But this is just the fact you are aware of. English is never as important as to prevent you from doing something you want or need. (Respondent 43)

Other respondents expressed the same idea by just mentioning "lack of motivation", "lack of opportunity to practice", "no need for everyday life", "daily routine is not connected with foreign language in any way", "my work and research has nothing to do with foreign language, so I just don't need it", "lack of knowledge about the opportunities to use the benefits of language literacy for my professional activity". Some of the respondents were touching the issue of motivation rather indirectly.

Mastering a foreign language is very time-consuming and I have no time for that. I wish I was not so busy.

So, I usually sit down to study English only when I have to take some test or an exam. (Respondent 33)

The second important negative factor named by students was the teaching process. It is noteworthy that the factors were grouped in the frequency order that differs from the positive factors order:

- insufficient number of English lessons;

- low level of General English;

- incompetent teachers (teachers don't know how to use modern technologies, teachers are not involved into research and scientific cooperation, teachers use the same set of drills and techniques disregarding the specificity of postgraduate education, the classroom language and/or home assignment is too difficult);

- outdated teaching materials, no suitable authentic textbooks covering all aspects of functional foreign language literacy;

- multilevel overcrowded learning groups.

In this respect an interesting dichotomy was observed. Speaking of positive and negative factors influencing functional foreign language literacy, most respondents were focusing on classroom learning process. However, they did not seem to value university classes as a means of functional foreign language literacy development, placing much more importance on real-life practice and work-related necessity.

The respondents were unexpectedly having difficulties trying to answer the question of possible changes in teaching and learning process that could help develop functional foreign language literacy. A great number of students (19) said they are more or less satisfied with the teaching process in general. A smaller part (9) wanted the lessons to be less exam-oriented.

Students should not be drilled and coached. It would be nice to have various activities in the class, not only those potentially helpful for passing the exam. (Respondent 1)

Just under a third of the respondents wished they could have a good balance between grammar revision and vocabulary learning. 4 participants said they were in desperate need of "scientific" vocabulary connected with their major. They said they were ready to learn the lists of words by heart, but neither of them mentioned reading as a potential source of new vocabulary.

The teachers' competence was another popular object for criticism and suggestions.

XLinguae, Volume 10, Issue 4, October 2017, ISSN 1337-8384, eISSN 2453-711X 
Teachers should undergo thorough assessment. Qualifications and articles published in prestigious journal should be taken into account. They should be sent to retraining courses and scientific conferences. Of course, there should be some financial incentives from the university to encourage teachers and to make these events affordable. (Respondent 25)

Quite few students (14) suggested alterations in the whole picture of language learning at the university. Apart from increasing the number of lessons and contact hours, students put forward an idea of widening the scope of real-life situations connected with using English. They insisted on creating an international academic environment by inviting foreign guest lecturers, attracting more Englishspeaking students, holding regular international events, making exchange programs for students much more accessible and affordable. 5 respondents found themselves underinformed about international academic opportunities and suggested the idea of providing students with channels of up-to-date and reliable information.

\section{Functional foreign language literacy for global research career development}

The inquiry into the students' perception of the link between functional foreign language literacy and successful international career of a researcher demonstrated a remarkable unanimity of opinion. Almost all respondents acknowledged the direct connection between these two phenomena. Some participants made quite verbose statements of the "utmost importance of functional foreign language literacy for planning a career of a professional scientist" (Respondent 33).

A career of a researcher implies a severe competition with many other scientists from different countries who may work over the same problem. One needs to know English to keep up with them and to share the results of the work. Besides, to keep oneself informed, a person has to read heaps of books and journals which are published outside Russia. (Respondent 2)

It $<$ functional foreign language literacy > is a great advantage. Is it really possible to become a true full-fledged scientist locking yourself up within the Russian borders? Sounds ridiculous. (Respondent 38)

In fact, it was the only moment of the interview when the respondents answered the question without a moment's hesitation. Some participants limited their answers to a short "Yes, of course" without specifying (12). 6 people gave a detailed justification of the statement. The underlying message of competition was perfectly understood and pronounced.

There were two respondents, though, holding opposing opinion that should not go unmentioned. In their view the notion of "career" was clearly separated from the sphere of scientific competition as a battle of minds and close to the "job ladder" concept.

No, it isn't an advantage for me, quite opposite. Successful research career in Russia is managed in its own ways. Success depends on many factors other than that. Scientists are not sponsored by the government or the institution. Even if they are, the red tape is appalling and the bureaucracy machine is agonizingly slow. You have to pay your own money for the conference participation, publishing in international journals and whatsoever. So, basically, you are just wasting time if you are learning foreign language to be competitive in this sphere. You can invest your time and efforts in other things. (Respondent 11) 
This opinion is an interesting angle of view which suggests the need for further research on the phenomenon of research career in Russia and its perception. Perhaps, it can be partly illustrated by the respondents' answers on the following question: Where and how are you going to pursue your research career? The answers of those wishing to continue their research career (29) were mostly in the line of academic achievement expectations and involved defending their thesis papers upon finishing the course of study at university. 16 out of 29 respondents were determined to pursue a doctoral degree (Candidate of Science), having made a reservation of "if I can afford it".

It is difficult to say whether I will have money and time to continue my research. I am afraid I will have to find a job which is not connected with education or research sphere. I am not married and I have to provide myself. (Respondent 22)

7 students were careful, but optimistic.

I might be interested in getting a PhD degree in the future. Time will show. (Respondent 14)

5 respondents were in doubt. 15 students were quite positive about their prospects of employment and said they were going to work as teachers at Southern Federal University. Out of the rest 16 respondents 7 people didn't mention completing their post-graduate studies as a stage in their careers. Their notions of further steps in the research career were quite vague.

I guess I will be writing papers to be published in various journals and participating in scientific conferences. (Respondent 36)

It's really hard to say. It looks like I am going to stay in Russia and do my research here. (Respondent 14)

Finally, 9 students were not having a research career in mind when talking of their future. Some of them (3) mentioned having problems with passing exams and showed little confidence.

I am not sure I will manage. I have a job and I can hardly attend classes. Well, I can cope with the thesis paper, but I am definitely going to have problems with all these tests and credits. (Respondent 33)

Intentions to maintain the level of functional foreign language literacy were explicit in the words of 25 students. Unfortunately, the answers on how one can make it possible were not numerous and included the following ideas:

- $\quad$ reading books and articles;

- $\quad$ attending language courses or taking private tutoring;

- $\quad$ practice speaking (no specification on was given);

- learning vocabulary.

15 students assured they understood the importance of developing their foreign language literacy but expressed concern about having a chance to do it.

That's a tricky question. It's too bad my language skills are worse now, when my English classes are over and I am not practicing. Unfortunately, 
right now there is nothing I can do about it. Perhaps, in future I will have time to continue learning English. (Respondent 4)

5 respondents said they were not going to maintain the level of functional foreign language literacy due to some reasons, such as:

I am starting a family and I will have no time for that in the foreseeable future. (Respondent 44)

I know it is important but I'm too busy. (Respondent 39)

To be honest, no, I am not going to do it. I am not very good at languages. Besides, my research is connected with Russian realia, so I don't have to read anything in English. (Respondent 32)

\section{Conclusion}

The findings of the standardized open-ended interview responses revealed a lack of clarity in the perception of the functional foreign language literacy phenomenon. The result gains additional significance if general absence of knowledge about functional literacy is taken into account. The respondents' awareness of the researched terms tends to be faint and fragmentary, showing no understanding of the socio-economic context. At the same time the meaning of the term "functional foreign language literacy" proved more deducible and suggesting the idea of using the language for one's professional communication. The self-assessment probe found that the level of functional foreign language literacy is felt as low and not sufficient by the vast majority of respondents. The supporting arguments for this opinion, though, are vaguely seen by the participants and pose a great difficulty to word. A great emphasis is given to formal academic assessment. The respondents tend to rely on such entity as feelings; the scope of real life situations provided as examples is limited to the context of learning and academic achievements.

The second part of the survey evidenced two major areas of students' concerns in developing functional foreign language literacy: the quality of classroom teaching process and a gap between learning and demands of real-life practice. Functional foreign language literacy of the teaching staff and adequacy of the teaching resources and methods were being questioned most often. Complaints about the lack of "language practice" clearly showed an interpretational ambivalence. One group of respondents understood language practice as classroom-isolated exercises aimed at developing listening and speaking skills while others meant work- and researchrelated situations requiring using a foreign language. While motivation is understood and appreciated as a powerful driving force, there is an obvious imbalance between internal and external motivation. Awareness of the importance of external motivation therefore retains speculative character and is not supported by coherent reasoning. Internal motivation is of sporadic nature and does not lead to consistent results. The respondents lack holistic approach in dealing with functional foreign language literacy development, being obsessed with specific language skills and methods of teaching.

The interview results showed that the research career is valued as part of the academic pursuits while not being regarded as a profitable job. In fact, it is often being opposed to a life-supporting occupation and treated as an additional spare time activity. The same approach is characteristic of students' perception of functional foreign language literacy development. In our view, the motives underlying such perspective require closer consideration in further studies. 
Summarizing the respondents' attitude to functional foreign language literacy, it should be noted that the phenomenon is seen as an integral part of global research career development. However, a considerable discrepancy is demonstrated between the stated intention and the readiness to take concrete actions suggesting that the true perception of the phenomenon is blurred, being insufficiently strengthened by the real-life demands.

Acknowledgements

The research was supported by the Russian Foundation for Basic Research grant $\mathrm{N}$ 17-36-01125 "Functional Literacy of Highly Qualified Scientific and Pedagogical

Personnel in Russia and the UK: Outcomes of the International Comparative Study".

\section{Bibliographic references}

BASOVA, E.A. 2012. Formation of functional communicative literacy by teenagers (on the basis of humanitarian subjects). PhD thesis. St. Petersburg. $221 \mathrm{p}$.

BROWNING, L. - THOMPSON, K. - DAWSON, D. 2017. From early career researcher to research leader: survival of the fittest? In: Journal of Higher Education Policy and Management, vol. 39, n. 4. ISSN 1360-080X. Available online: http://www.tandfonline.com/doi/full/10.1080/1360080X.2017.1330814

CHIGISHEVA, O. 2015. Lifelong Transition Trajectory for the International Researcher. In: Procedia-Social and Behavioral Sciences, vol. 180, pp. 268-273. ISSN 1877-0428.

CHIGISHEVA, O.P. - SOLTOVETS, E.M. - BONDARENKO, A.V. 2016. The role of formal and informal components in the increase of functional foreign language literacy by SFU staff: survey results. In: International Journal of Economics and Education, vol. 2, n. 3, pp. 7-21. ISSN 2411-2046.

CROSS-BORDER PARTNERSHIPS IN HIGHER EDUCATION. STRATEGIES AND ISSUES. 2011. New York-Oxon: Taylor \& Francis-Routledge. ISBN 978-0415-87648-3.

DRASKOVIC, M. - MILICA, D. - MLADEN, I. - CHIGISHEVA, O. 2017. Preference of institutional changes in social and economic development. In: Journal of International Studies, vol. 10, n. 2, pp. 318-328. ISSN 2306-3483.

FEDOTOVA, O. - CHIGISHEVA, O. 2015. Comparative analysis: Methodological optics in the ideological context. In: International Perspectives on Education and Society, vol. 26, pp. 57-82. ISSN 1479-3679.

GROENEWALD, T. 2004. A phenomenological research design illustrated. In: International Journal of Qualitative Methods, vol. 3, n. 1, article 4. ISSN 1609-4069. Available online: http://www.ualberta.ca/ iiqm/backissues/3_1/pdf/groenewald.pdf.

HAN, S.D. - BOYLE, P.A. - ARFANAKIS, K. - JAMES, B.D. - BENNETT, D.A. 2016. Financial literacy is associated with white matter integrity in old age. In: NeuroImage, vol. 130, pp. 223-229. ISSN 1053-8119.

KERN, R. - SCHULTZ, J.M. 2005. Beyond orality: Investigating literacy and the literary in second and foreign language instruction. In: Modern Language Journal, vol. 89, n. 3, pp. 381-392. ISSN 1540-4781.

KIRTCHIK, O. 2012. Limits and Strategies for the Internationalization of Russian Economic Science: Sociological Interpretation of Bibliometric Data. In: Laboratorium: Russian Review of Social Research, vol. 4, n. 1, pp. 19-44. ISSN 20768214.

KLYUCHAREV, G. - OGAREV, E. 2002. Continuous education within a transformations. M.: ROSSPEN. 108 p. ISBN 5-94009-006-0.

KOLESNIKOVA, I.A. 2013. New literacy and new illiteracy of the 21st Century. In: Scientific Electronic Quarterly Journal Continuing Education: 21st Century, vol. 2.

XLinguae, Volume 10, Issue 4, October 2017, ISSN 1337-8384, eISSN 2453-711X 
ISSN 2308-7234. Available online: https://cyberleninka.ru/article/n/novayagramotnost-i-novaya-negramotnost-dvadtsat-pervogo-stoletiya

KUZ'MINA, YU.V. - POPOV, D.S. 2015. Adults' literacy as mechanism for their societal inclusion. In: Sotsiologicheskie Issledovaniya, vol. 7, pp. 48-57. ISSN 01321625.

LARSEN-FREEMAN, D. - ANDERSON, M. 2011. Techniques \& Principles in Language Teaching. Oxford: Oxford University Press. ISBN 978-0-19-4-42360-1.

LEBEDEV, O.E. 2005. Competence approach in education. In: School technologies, n. 5, pp. 3-13. ISSN 2220-2641.

MARGINSON, S. 2014. Russian science and higher education in a more global era. In: Educational Studies, vol. 4, pp. 8-35. ISSN 1814-9545.

MATSKEVICH, V. - KRUPNIK, S. 2001. Functional literacy. In: World Encyclopedia: Philosophy. Minsk: Harvest. 312 p. ISBN 5-17-007278-3.

PORTNOI, L.M. - RUST, V.L. - BAGLEY, S.S. 2010. Mapping the Terrain: The Global Competition Phenomenon in Higher Education. In: Higher Education, Policy, and the Global Competition Phenomenon. Los Angeles: PALGRAVE MACMILLAN, pp. 1-13. ISBN 978-0-230-61818-3.

REID, E. 2015. Techniques Developing Intercultural Communicative Competences in English Language Lessons. In: Procedia-Social and Behavioral Sciences, vol. 186, pp. 939-943. ISSN 1877-0428.

RESEARCH METHODS IN EDUCATION. 2007. Oxon: Routledge, pp. 352-356. ISBN 0-415-37410-3.

SMOLENTSEVA, A. 2017. Universal higher education and positional advantage: Soviet legacies and neoliberal transformations in Russia. In: Higher Education, vol.73, n. 2, pp. 209-226. ISSN 0018-1560.

PASSPORT OF THE PRIORITY PROJECT DEVELOPMENT OF THE EXPORT POTENTIAL OF THE RUSSIAN SYSTEM OF EDUCATION. 2017. Available online: http://d-russia.ru/wp-content/uploads/2017/06/education_export.pdf

PRESIDENT'S DECREE N 967 "ON MEASURES TO DEVELOP HUMAN RESOURCE POTENTIAL OF THE RUSSIAN FEDERATION”. 2013. Available online: http://educationglobal.ru/fileadmin/downloads/1_УКА3_Президента.pdf

STATE PROGRAM GLOBAL EDUCATION. ${ }^{-}$2014. Available online: http://educationglobal.ru/ns/overview/

STUKALOVA, I. - SHISHKIN, A. - STUKALOVA, A. 2015. Internationalization of higher education: a case of Russian universities. In: Economics and Sociology, vol. 8, n. 1, pp. 275-286. ISSN 2306-3459.

VAN VUGHT, F. 2008. Mission Diversity and Reputation in Higher Education. In: Higher Education Policy, vol. 21, n. 2, pp. 151-174.

THE CONCEPT OF THE FEDERAL TARGETED PROGRAM "DEVELOPMENT OF EDUCATION FOR 2016-2020". 2014. Available online: http://government.ru/docs/16479/

THE PROGRAM "GLOBAL EDUCATION" WILL BE EXTENDED. 2016. Available online: http://edugid.ru/news/261-programmu-global-noe-obrazovanieprodlyat

TOWARDS A EUROPEAN FRAMEWORK FOR RESEARCH CAREERS. 2011. Available online: http://www.etag.ee/wpcontent/uploads/2017/01/Towards_a_European_Framework_for_Research_Careers_fi nal.pdf

TRENDS SHAPING EDUCATION 2016. 2016. Available online: http://www.oecdilibrary.org/education/trends-shaping-education-2016_trends_edu-2016-en

TSUBAKITA, T. - KAWAZOE, N. - KASANO, E. 2017. A new functional health literacy scale for Japanese young adults based on item response theory. In: AsiaPacific Journal of Public Health, vol. 29, n. 2, pp. 149-158. ISSN 1010-5395. 
UHUEGBU, A.R. - EDUNG, M.T.U. 2015. Functional foreign language literacy for higher education and research: The case of French in Nigerian universities. In: Arts and Humanities in Higher Education, vol.14, n. 4, pp. 398-408. ISSN 1474-0222.

UNESCO. REVISED RECOMMENDATION CONCERNING THE INTERNATIONAL STANDARDIZATION OF EDUCATIONAL STATISTICS. 1978. General Conference of UNESCO. Paris, 27.09.1978. Available online: http://portal.unesco.org/en/ev.php-

URL_ID\%3D13136\%26URL_DO\%3DDO_TOPIC\%26URL_SECTION\%3D201.ht $\mathrm{ml}$

VERSHLOVSKY, S.G. - MATYUSHKINA, M.D. 2007. School leavers functional literacy. In: Sociological research, n. 5, pp. 140-144. ISSN 0132-1625.

YAKOVLEVA, K. 2016. Big Challenges: Why Global Education does not work? Available online: https://www.ucheba.ru/article/2121

ZHANG, Y. 2017. Supporting English Language Learners in Social Studies: Language-focused Strategies. In: The Social Studies, vol. 108, n. 5, pp. 1-6. ISSN 0037-7996.

Available

online:

http://www.tandfonline.com/doi/full/10.1080/00377996.2017.1354808

Words: 7787

Characters: 53031 (29,46 standard pages)

Assoc.Prof. Oksana Chigisheva, $\mathrm{PhD}$

Anna Bondarenko

Academy of Psychology and Educational Sciences

Department of Education and Pedagogical Sciences

Southern Federal University

105/42 Bolshaya Sadovaya Str.

344006 Rostov-on-Don

Russia

opchigisheva@sfedu.ru

anuta060693@mail.ru

Senior Lecturer Elena Soltovets

Institute of Philology, Journalism and Intercultural Communication

Department of English for Humanities

Southern Federal University

105/42 Bolshaya Sadovaya Str.

344006 Rostov-on-Don

Russia

hsolt@sfedu.ru

XLinguae, Volume 10, Issue 4, October 2017, ISSN 1337-8384, eISSN 2453-711X 